\title{
The Use of Social Media as Learning Media among High School Student: A Case study of Pangkajene and Islands
}

\author{
Muhammad Farid ${ }^{1}$, A. Alimuddin Unde $^{2}$, Nosakros Arya ${ }^{3}$ \\ \{faridemsil@yahoo.com¹, undealimuddin@yahoo.co.id²,nosakros@gmail.com ${ }^{3}$ \} \\ Department of Communication Science, Faculty of Social and Political Sciences, Universitas Hasanuddin, Jl. \\ Perintis Kemerdekaan KM. 10. Makassar, Indonesia
}

\begin{abstract}
This study aims to investigate the use of social media as an alternative media in student education. It employs qualitative method and data was collected through direct interviews, focus group discussions and daily observations. The study was conducted in Pangkajene Regency. The results showed that there were differences in social media use between students from Senior High School 1 Liukang Tupabiring Utara and Senior High School 2 Pangkajene. These differences can be associated to geographical factors leading to a discrepency in internet accessibility that ultimately affected social media usage behavior. Data shows that the majority of students of Senior High School 1 Liukang Tupabbiring Utara, which is located on the small island of Sagara roughly 4.5 kilometers from the Makassar coastline, did not use social media for educational purposes with many claiming to have never sought out educational information through social media. This is in stark contrast to the social media usage behavior of students in Senior High School 2 Pangkajene, which is several kilometers inland on the South Sulawesi mainland, who were far more likely to use social media for learning.
\end{abstract}

Keywords: New media, Education, High school, Island settlements

\section{Introduction}

The use of social media for education is a relatively new topic of interest in communication science research. It began becoming a serious subject for scholarship during the early stages of the modern era of communication and information technology that led to new levels of smartphone affordability and resulted in a boom in internet accessibility throughout the globe.

The ubiquity of social media in our daily lives has inspired many educators to utilize it as a teaching tool. Teachers are using Facebook to create closed groups with their students that serve as digital forums for sharing ideas and asking questions outside of the formal school environment. They are also using these groups" "walls" to share learning materials, assign homework, and schedule class events. Meanwhile, YouTube has grown into an invaluable resource for information on nearly any subject imaginable, with many colleges and universities creating their own channels where they upload videos of entire lectures. Educational institutions and other organizations 
working in the education industry are also using social media to foster discussion with their audience at a scale and speed unrivaled by previous technologies.

Indonesia has the largest populations of social media users in the world outside of China, and it's still growing. According to a 2019 study by the media company We Are Social in collaboration with Hootsuite, there are approximately 150 million social media users in Indonesia. This is up 20 million users from 2018. Facebook is the most popular social media platform in Indonesia with 81 percent penetration. Instagram, which is also owned by Facebook, has become the second most popular social media platform in Indonesia with 80 percent penetration. The top five messaging apps in Indonesia are: Facebook, Instagram, Twitter, Snapchat, and LinkedIn. Additionally, YouTube has reached 88 percent penetration and WhatsApp has 83 percent penetration [1]. Research by Digital Life (TNS) revealed that approximately 30,000,000 internet users in Indonesia are active on social networks every day (largely Facebook and Twitter) with the largest demographic being teenagers [2].

The internet and social media have proven to be historically important in the development of education and learning and their benefits are clear. It is important to note, however, that there remain many regions where internet accessibility is either limited or impossible. This raises the question: what differences exist between the social media usage behaviors of students in regions where internet is easily accessed to that of students in regions where internet access is limited? This study aims to explore the answer the to this question by looking at the social media usage behaviors of high school students in the regency of Pangkajene and Islands in the province of South Sulawesi, Indonesia.

Social media is online media that enables social interaction through web-based technology, transforming communication into interactive dialogue [3]. Kaplan and Haenlein [4] define social media as "a group of Internet-based applications that build on the ideological and technological foundations of Web 2.0, and that allow the creation and exchange of user-generated content". Indonesia is the country with the most social media users in the world.

Simply put, social media are tools for sharing and socializing. Applications such as Facebook and Twitter can also have uses in teaching and learning activities, such as through the forming of online study groups on Facebook. Building on that idea, such study groups on social media platforms may function as hubs where members can share interesting articles, relevant news, and ask questions related to the class.

Social media is an example of "new media" and thus New Media Theory is used as a foundation for measurement and analysis within this study. Researchers consider this theory relevant to the existence of social media which is a newcomer in the realm of media. New media is a term intended to encompass the emergence of digital, computer, or information and communication technology networks in the late 20th century. Most of the technologies described as "new media" are digital, often having characteristics that can be manipulated, are networked, dense, incompressible, interactive and impartial. Some examples of new media are the Internet, websites, multimedia computers, computer games, CD-ROMS, and DVDs. Television, film, magazines, books, or paperbased publications are not considered new media.

From a social integration perspective, media is not information, interaction, or its dissemination, but rather a ritual which man uses to create communities. Media is not just an instrument of information or a way to fulfill personal interests, but it unites us as a community and gives us a sense of belonging. 
The New Media Theory is still in the early stages of development and there is much work to be done to perfect and broaden some of the basic arguments that it lays down. Arranging things in a 'modernist' and 'postmodern' context, has helped to clarify many of the big debates that take place. 'Digital theory' may not yet be considered a "proper" discipline, but its presence will be felt and influence the definition of New Media long into the future.

The Uses and Gratifications approach was first introduced by Alihu Katz in Effendy [5]. Uses and Gratifications show that the main problem is not how media changes the attitudes and behavior of the audience, but how the media meets their personal and social needs. So, the crux lies on an active audience that actively uses the media to achieve specific goals.

According to Katz, Gurevitch, and Haas, as quoted by Effendy in his book entitled "Science, Theory and Philosophy of Communication" [5], the Uses and Gratifications model starts with the social environment that determines our needs. The social environment includes the characteristics of group affiliation and personality traits. [5]

Blumer as quoted by Jalaluddin Rachmat [6] said that, there are three uses and gratifications orientation theories, namely:

- Cognitive (the need for information surveillance, or exploration of reality)

- Diversion (the need for relief from pressures and the need for entertainment), and

- Personal identity (ie using this media to reinforce or accentuate something important in the life and situation of the audience itself).

\section{Research Method}

This research uses a quantitative approach by asking questions through a questionnaire regarding the use of social media for various purposes including education. This study collected data by survey conducted by self-administrated questionnaire.

The data that has been collected and processed are analyzed with quantitative analysis techniques to make decisions or conclusions from the results of research. The end result, in turn, gives birth to new ideas. The secondary data obtained from the results of short interviews with respondents and the results of field observations at the research site.

Respondents were students of Senior High School 2 Pangkajene, Regency of Pangkajene and Kepulauan, South Sulawesi, amounting to 81 people and students of Senior High School 1 Liukang Tupabiring Utara, Pangkajene And Kepulauan Regency, South Sulawesi, amounting to 71 people.

Geographically, Senior High School 2 Pangkajene, Pangkajene and Kepulauan Regency, is located in the plain with the island of Sulawesi. While North Liukang Tupabiring 1 High School, Pangkajene and Kepulauan Regency are located on a different terrain from Pangkajene 2 Public High School, which is in the archipelago, precisely on the island of Balang Lompo.

\section{Results and Discussion}

\subsection{Effectiveness of Social Media Utilization as Learning Media}


Table 1. Gender

\begin{tabular}{cccccccc}
\hline & \multicolumn{3}{c}{ Senior High School 2 Pangkajene } & \multicolumn{3}{c}{ Senior High School 1 North Liukang } \\
Tupabbiring
\end{tabular}

Of the students of Senior High School 2 Pangkejen, 32 were boys and 49 were girls. There was a greater number of girls than boys. Whereas of the respondents from Senior High School 1 Liukang Tupabbiring Utara, 21 were boys and 50 were girls.

Table 2. Places to Access Social Media Other Than School

\begin{tabular}{|c|c|c|c|c|c|c|c|c|c|}
\hline \multicolumn{6}{|c|}{ Senior High School 2 Pangkajene } & \multicolumn{4}{|c|}{$\begin{array}{c}\text { Senior High School } 1 \text { North Liukang } \\
\text { Tupabbiring }\end{array}$} \\
\hline & Frequency & Percent & $\begin{array}{c}\text { Valid } \\
\text { Percent }\end{array}$ & $\begin{array}{l}\text { Cumulative } \\
\text { Percent }\end{array}$ & & Frequency & Percent & $\begin{array}{c}\text { Valid } \\
\text { Percent }\end{array}$ & $\begin{array}{l}\text { Cumulative } \\
\text { Percent }\end{array}$ \\
\hline Home & 33 & 40.8 & 40.8 & 40.8 & $\begin{array}{l}\text { Internet } \\
\text { Café }\end{array}$ & 2 & 2.8 & 2.8 & 100.0 \\
\hline $\begin{array}{l}\text { Internet } \\
\text { Cafe }\end{array}$ & 30 & 37.0 & 37.0 & 77.8 & $\begin{array}{l}\text { Personal } \\
\text { Phone }\end{array}$ & 69 & 97.2 & 97.2 & 97.2 \\
\hline Other & 18 & 22.2 & 22.2 & 100 & & - & - & - & - \\
\hline
\end{tabular}

Of the students of Senior High School 2 Pangkajene, 33 accessed social media from home (40.7 percent), 30 at internet cafes (22.2 percent), with the remaining accessing social media at a neighbor's home or from their personal phone. In contrast, 69 (97.2 percent) of the students of Liukang Tupabbiring Utara accessed social media at internet cafes with the remaining 2 (2.8 percent) accessing social media from their phones.

Table 3. Duration of Social Meda Use for Educational Purposes 


\begin{tabular}{ccccccccc}
\hline & Frequency & Percent & $\begin{array}{c}\text { Valid } \\
\text { Percent }\end{array}$ & $\begin{array}{c}\text { Cumulative } \\
\text { Percent }\end{array}$ & Frequency & Percent & $\begin{array}{c}\text { Valid } \\
\text { Percent }\end{array}$ & $\begin{array}{c}\text { Cumulative } \\
\text { Percent }\end{array}$ \\
\hline$<1$ hour & 16 & 19.8 & 19.8 & 19.8 & 34 & 47.9 & 47.9 & 47.9 \\
1 hour & 16 & 19.8 & 19.8 & 39.6 & 18 & 25.4 & 25.4 & 73.2 \\
2 hours & 20 & 24.7 & 24.7 & 64.2 & 15 & 21.1 & 21.1 & 94.4 \\
$>3$ hours & 29 & 35.8 & 35.8 & 100.0 & 4 & 5.6 & 5.6 & 100.0 \\
Total & $\mathbf{8 1}$ & $\mathbf{1 0 0 . 0}$ & $\mathbf{1 0 0 . 0}$ & & $\mathbf{7 1}$ & $\mathbf{1 0 0 . 0}$ & $\mathbf{1 0 0 . 0}$ & \\
\hline
\end{tabular}

22 (27.2 percent) students of Senior High School Pangkajene answered that they used social media for educational purposes more than 3 hours, 16 said they used it for less than an hour. In Senior High School 1 Liukang Tupabbiring Utara, 4 (5.6 percent) students answered that they used social media for educational purposes for more than 3 hours and 34 ( 47.9 percent) said they used it less than 1 hour.

Table 4. Social Media for Educational Purposes

\begin{tabular}{|c|c|c|c|c|c|c|c|c|}
\hline & \multicolumn{4}{|c|}{ Senior High School 2 Pangkajene } & \multicolumn{4}{|c|}{$\begin{array}{c}\text { Senior High School } 11 \text { North Liukang } \\
\text { Tupabbiring }\end{array}$} \\
\hline & $\begin{array}{c}\text { Freq } \\
\text { uenc } \\
y\end{array}$ & Percent & $\begin{array}{l}\text { Valid } \\
\text { Percent }\end{array}$ & $\begin{array}{l}\text { Cumulative } \\
\text { Percent }\end{array}$ & Frequency & Percent & $\begin{array}{l}\text { Valid } \\
\text { Percent }\end{array}$ & $\begin{array}{l}\text { Cumulative } \\
\text { Percent }\end{array}$ \\
\hline $\begin{array}{l}\text { Facebook and } \\
\text { YouTube }\end{array}$ & 37 & 45.7 & 45.7 & 45.7 & 4 & 5.6 & 5.6 & 5.6 \\
\hline Only Facebook & 1 & 1.2 & 1.2 & 46.9 & 5 & 7.0 & 7.0 & 12.7 \\
\hline Only YouTube & 29 & 35.8 & 35.8 & 82.7 & 5 & 7.0 & 7.0 & 19.7 \\
\hline Others & 14 & 17.3 & 17.3 & 100.0 & 57 & 80.3 & 80.3 & 100.0 \\
\hline Total & 81 & 100.0 & 100.0 & & 71 & 100.0 & 100.0 & \\
\hline
\end{tabular}

For respondents for Senior High School 2 Pangkajene Social media which is used for the most educational purposes is a combination of Facebook and YouTube 37 people (45.7 percent) following only using YouTube 29 people (35.8 percent) and at least only using Facebook. While others, in the form of WA, Instagram, Line 14 people (17.3 percent). Whereas for Respondents from Senior High School 1 Liukang Tupabbiring Utara Social media that is used for the most educational purposes is a combination of Facebook and YouTube 4 people (5.6 percent) following only using YouTube 5 people (7 percent) and only using Facebook 5 people (7 percent) and those who use Facebook no use at all 57 people ( 80.3 percent).

Table 5. Social Media for Educational Purposes 


\begin{tabular}{|c|c|c|c|c|c|c|c|c|c|}
\hline & Frequency & Percent & $\begin{array}{c}\text { Valid } \\
\text { Percent }\end{array}$ & $\begin{array}{c}\text { Cumulative } \\
\text { Percent }\end{array}$ & & Frequency & Percent & $\begin{array}{c}\text { Valid } \\
\text { Percent } \\
\end{array}$ & $\begin{array}{c}\text { Cumulative } \\
\text { Percent }\end{array}$ \\
\hline $\begin{array}{l}\text { Completing } \\
\text { homework }\end{array}$ & 47 & 58.0 & 58.0 & 58.0 & $\begin{array}{l}\text { Completing } \\
\text { homework }\end{array}$ & 10 & 14.8 & 14.8 & 14.8 \\
\hline $\begin{array}{l}\text { Looking for } \\
\text { the Latest } \\
\text { References } \\
\text { Related to } \\
\text { School } \\
\text { Lessons }\end{array}$ & 18 & 22.2 & 22.2 & 80.2 & $\begin{array}{l}\text { Looking } \\
\text { for the } \\
\text { Latest } \\
\text { References } \\
\text { Related to } \\
\text { School } \\
\text { Lessons }\end{array}$ & 4 & 5.6 & 5.6 & 20.4 \\
\hline $\begin{array}{l}\text { Looking } \\
\text { for Practice } \\
\text { Questions }\end{array}$ & 9 & 11.1 & 11.1 & 91.4 & $\begin{array}{l}\text { Did not } \\
\text { search }\end{array}$ & 57 & 64,8 & 64.8 & 100.0 \\
\hline Others & 7 & 8.6 & 8.6 & 100.0 & & & & & \\
\hline Total & 81 & 100.0 & 100.0 & & Total & 71 & 100.0 & 100.0 & \\
\hline
\end{tabular}

Students of Senior High School 2 Pangkajene used social media to aid them in completing homework, discovering new references, and finding practice problems. Whereas only 10 (14.8 percent) students of Senior High School 1 Liukang Tupabbiring Utara used social media to help complete their homework and 4 (5.6 percent) using social media to find new references. A staggering 57 (64.8 percent) tdid not use social media at all.

Table 6. Other Obstacles to Social Media as Learning Media

\begin{tabular}{|c|c|c|c|c|c|c|c|c|}
\hline & \multicolumn{4}{|c|}{ Senior High School 2 Pangkajene } & \multicolumn{4}{|c|}{$\begin{array}{c}\text { Senior High School } 1 \text { North Liukang } \\
\text { Tupabbiring }\end{array}$} \\
\hline & Frequency & Percent & $\begin{array}{c}\text { Valid } \\
\text { Percent }\end{array}$ & $\begin{array}{c}\text { Cumulative } \\
\text { Percent }\end{array}$ & Frequency & Percent & $\begin{array}{c}\text { Valid } \\
\text { Percent }\end{array}$ & $\begin{array}{c}\text { Cumulative } \\
\text { Percent }\end{array}$ \\
\hline $\begin{array}{c}\text { Some } \\
\text { Information was } \\
\text { Unavailable }\end{array}$ & 29 & 35.8 & 35.8 & 35.8 & 4 & 5.6 & 5.6 & 5.6 \\
\hline $\begin{array}{l}\text { Incomplete } \\
\text { Information }\end{array}$ & 32 & 39.5 & 39.5 & 75.3 & 5 & 7.4 & 7.4 & 13.0 \\
\hline $\begin{array}{l}\text { Information is } \\
\text { only available in } \\
\text { a foreign } \\
\text { language }\end{array}$ & 13 & 16.0 & 16.0 & 91.4 & 5 & 7.4 & 7.4 & 18.6 \\
\hline Others & 7 & 8.6 & 8.6 & 100.0 & 57 & 68.8 & 68.8 & 100.0 \\
\hline Total & 81 & 100.0 & 100.0 & & 71 & 100.0 & 100.0 & \\
\hline
\end{tabular}

Constraints found in addition to technical constraints, namely incomplete information, using foreign languages and others. 


\subsection{Field Observations}

\section{Lack of Internet Access}

Based on field observations, the geographical conditions of Senior High School 1 Liukang Tupabbiring Utara which is located outside the island of Sulawesi has limited internet network. This resulted in the information to be downloaded requires a rather long time. The same thing is almost the same happened in Senior High School 2 Pangkajene, which is an internet network that is often disrupted, the signal is less strong.

2. Limited Electricity Availability

Another technical obstacle for students of Senior High School 1 Liukang Tupabbiring Utara is limited access to electricity during the day. Power outages during the day result in the community having to wait for time to use electricity again at night. While electricity is the main source for media access devices to stay on.

3. Limited Understanding of the Uses of Social Media

In addition to these technical factors, another factor obtained from the results of field observations at Senior High School 1 Liukang Tupabbiring Utara is that the skills of some students to use social media are still limited. Only a handful of students are able to take advantage of social media facilities, such as Facebook, line, YouTube, Instagram and others. So the use of social media has not spread too much to other students, especially because of the economic ability of middle and lower students so that they do not have an Android mobile to be used to access Social Media, to get educational information, especially those related to lessons in school.

\subsection{Utilization of Social Media as Learning Media}

The results showed there were differences in how to use social media between students from Senior High School 1 Liukang Tupabiring Utara and Senior High School 2 Pangkajene. The author assumes that the geographical location also influences the condition.

The results of field observations by interviewing students explained that the limitations of internet network access, electricity access in the island area and the limited knowledge of the use of social media influenced students to utilize social media as a learning medium. The data shoes that 57 of the students of Senior High School 1 Liukang Tupabbiring Utara that participated in this study did not use social media for educational purposes (Table 4). The same data shows that 57 students admitted to never searching for educational materials through social media (Table 5).

This is in complete contrast to the social media behavior patterns show by the students of Senior High School 2 Pangkajene. 67 students (Senior High School 2 Pangkajene) used social media for educational purposes (Table 4). These students chose YouTube and Facebook as the social media platforms of choice for discovering and accessing information relating to their educations. 49 of these students used social media as a learning medium for periods of greater than 2 hours a day.

Table 6 shows some obstacles students from both schools faced in accessing and using social media for learning purposes. There are clear differences between the two schools which may be associated with the contrast in social media usage patterns. In Senior High School 2 Pangkajene, 74 of the 81 students involved in this study claimed that incomplete information and the information only being available in a foreign language as the two primary obstacles to their usage of social media 
for learning. But 57 out of 71 students in North Tupabbiring 1 high school actually did not experience problems related to information. That is because 57 students in Senior High School 1 Tupabbiring Utara did not use social media for educational purposes.

Although according to the results of field observations, in the area of Pangkajene 2 Public High School they also experience limited access to the internet network, but the results of the observation also show that there is no limitation of the knowledge of Pangkajene 2 Public High School students in accessing social media. This affects the difference in the way students use social media as a learning medium in two high schools with different geographical locations.

The results of the study are in line with the Uses and Gratification model which says that the social environment determines our needs. The social environment includes the characteristics of group affiliation and personality traits [5]. Where and where groups come from determines their needs using media. As Blumer said in Rachmat that the cognitive aspects or the need for information surveillance, or the exploration of reality determine the way we use media [6].

What these students are doing is to answer the challenges of the rapid era, responding to the development of communication and information technology that is so fast developing, that they are "forced" to use information technology, before they are left behind by the rapid development. However, this study illustrates how coastal communities have different patterns in accessing media.

\section{Conclusion}

From the results of the study it can be concluded, there are differences in how to use social media between students from Senior High School 1 Liukang Tupabiring Utara and Senior High School 2 Pangkajene. These differences can be associated to geographical location which also affects the conditions in using social media. The results of field observations by interviewing students explained that the limitations of internet network access, electricity access in the island area and the limited knowledge of the use of social media influenced students to utilize social media as a learning medium. Data shows that 57 students of Liukang Tupabbiring Utara Senior High School as many as 57 people did not use social media for educational purposes and even 57 people claimed not to seek educational information through social media, in contrast to students from Senior High School 2 Pangkajene who used social media more as learning media.

For effective social media usage, all parties must utilize the available island internet network. So students can use several social media with the maximum for their educational needs, so as not to miss information. Related parties should pay attention to the quality of the internet network for the mainland so that there is no need for complaints that network problems are often not optimal.

Constraints in the use of social media for educational purposes in the archipelago need to prepare ITK laboratories so that all students can enjoy and use them for educational purposes. Internet network must be maximized so that there are no more complaints about weak signals, failed downloads and the like. The school needs to increase the ability of Wifi. 


\section{References}

[1] W. K. Pertiwi.: Facebook Jadi Medsos Paling Digemari di Indonesia. https://tekno.kompas.com/read/2019/02/05/11080097/facebook-jadi-medsos-palingdigemari-di-indonesia. Kompas.com Jakarta (2019)

[2] R. Riyadi.: Penggunaan Media Sosial Sebagai Media Pembelajaran. Kompasiana.com (2018)

[3] H. Tahir.: Media Sosial Dalam Kehidupan Manusia. http://harrytahir2.blogspot.com/ 2013/04/karya-tulis-ilmiah-media-sosial-dan.html (2019)

[4] Kaplan A. M. and M. Haenlein.: Users of the world, unite! The challenges and opportunities of Social Media. Business Horizons, Vol. 53. pp. 59-68 (2010)

[5] Effendy O. U.: Ilmu, Teori \& Filsafat Komunikasi, Bandung: PT CItra Aditya Bakti (1993)

[6] Rakhmat. J.: Psikologi Komunikasi, Bandung: PT Remaja Rosdakarya.(2007) 